\title{
Difficult Airway Management in an Infant with Full Face and Neck Burn
}

\author{
Hülya Özay, Tamer Kuzucuoğlu, Oğuzhan Kılavuz, Hakan Acar
}

\begin{abstract}
Department of Anesthesiology and Reanimation, Kartal Dr. Lütfi Kırdar Training and Research Hospital, İstanbul, Turkey

Submitted: 25.10 .2013 Accepted: 18.12 .2013

Correspondence: Tamer Kuzucuoğlu, Akasya Acıbadem Gölkule, No: 3, Üsküdar, İstanbul, Turkey E-mail: tamer.kuzucuoglu@sbkeah.gov.tr

Keywords: Airway
obstruction; burns; infant.
\end{abstract}

\begin{abstract}
Burns that occur in the first 2 decades of life are usually caused by preventable accidents. Scald burns are the most common in the first decade. Flame burns have high morbidity and mortality rates in infants. This case report is presented to demonstrate appropriate anesthesia management and the multidisciplinary approach required in an intensive care unit (ICU). A 35 -day-old infant was admitted to ICU with second and third degree flash burns on the face, neck, and body covering $18 \%$ total body surface area according to Lund and Browder chart. Patient also had facial and oral edema, which resulted in difficult airway (grade IV). Burns were secondary to an accident at home involving matches lit by her brother.
\end{abstract}

\section{INTRODUCTION}

Burns rank third among traumas with resultant mortality. ${ }^{[1]}$ In infants, most frequently scald burns are seen, followed by flame burns, thermal burns, and electrical burns. Most flame burns occur in children aged $\geq 5$ years, while electrical burns are often seen in patients $\geq 13$ years of age. Scald burns least frequently lead to death, while flame burns are type that most often results in death. ${ }^{[l]}$

In children, the trachea is short and narrow, and the glottis appears more anteriorly. Smaller diameter of airway means there is greater risk of occlusion with debris or secretions. Since children have less ability to escape fire, they are frequently exposed to associated inhalation injury. Carbon monoxide poisoning and bronchospasm are often seen in cases of flame burns. In the present patient, carboxyhemoglobin level and pulmonary radiograms were within normal limits, which ruled out these possibilities.

\section{CASE REPORT}

A 15-day-old infant girl weighing $3 \mathrm{~kg}$ without systemic disease was presented to intensive care unit (ICU) with second and third degree burns covering $18 \%$ of body surface area (BSA) according to Lund and Browder chart classification (full face, ears, hair, from cranium to vertex, and neck) (Figure Ia). Four hours after incident of burn, patient was admitted to emergency service. On first examination, because of development of tachypnea (respiratory rate: $>40 / \mathrm{min}$ ), and desaturation $(\mathrm{SpO} 2<90 \%)$, patient was intubated through orotracheal route (Portex tracheal tube no. 3 without cuff; Smiths Medical, Kent, England), and connected to pressure-controlled mechanical ventilation (MV). Through right femoral vein, central venous pressure catheter with a 3-way tap was inserted. At admission to burn intensive care unit, following vital signs were detected in intubated and sedated patient: worse state of general health; inability to open eyes because of periorbital edema; motor responses: mobile bilateral extremities, post-inhibitory rebound $+/+$, isochoric pupillae; bilateral and symmetrical breath sounds of equal intensity; maximum heart rate (MHR): 152/bpm; blood pressure (BP): $87 / 52 \mathrm{mmHg}$; fever: $36.5^{\circ} \mathrm{C}$; $\mathrm{SpO} 2: 99 \%$; venous blood gas parameters: $\mathrm{pH}$ : 7.08, $\mathrm{PaCO} 2: 52.3 \mathrm{mmHg}, \mathrm{PaO} 2: 36.3$ 
$\mathrm{mmHg}, \mathrm{HCO}$ : $15.2 \mathrm{mmoL} / \mathrm{L}$, base excess (BE): -14.6 , hemoglobin $(\mathrm{Hb})$ : $11.5 \mathrm{~g} / \mathrm{dL}$, hematocrit $(\mathrm{Hct}): 31.4 \%$, white blood cell count: $38400 / \mathrm{mm}^{3}$, platelet count: $756000 / \mathrm{mm}^{3}$, international normalized ratio: I.09, Na: $132 \mathrm{meq} / \mathrm{L}, \mathrm{K}: 5.2$ meq/L, Cl: $107 \mathrm{meq} / \mathrm{L}, \mathrm{Ca}:$ I I meq/L, blood urea nitrogen: $23 \mathrm{mg} / \mathrm{dL}$, creatinine: 0.9, fasting blood glucose (FBG): 93 $\mathrm{mg} / \mathrm{dL}$, albumin $2.4 \mathrm{~g} / \mathrm{dL}$, aspartate aminotransferase: $1 / 2$ $\mathrm{U} / \mathrm{L}$, and alanine aminotransferase: $25.4 \mathrm{U} / \mathrm{L}$. Patient was monitored and provided with MV support in synchronized intermittent mandatory ventilation-positive pressure (SIMV-P) mode (FiO2: 0.50, frequency [f]: 40/min, positive end expiratory pressure/peak inspiratory pressure: $2 / 10$ ). A 6 French urethral Foley catheter was inserted. Body surface area (BSA) was calculated based on Jacobsen formula (height $[\mathrm{cm}]+$ body weight $[\mathrm{kg}]-60 / 100)$. Infusion of Izomix I/2 solution was initiated at a rate determined according to Shriner's Burns Hospital-Galveston formula (first 24 hours: $5000 \mathrm{~mL} / \mathrm{m}^{2}$ burned area + maintenance, $\left.2000 \mathrm{~mL} / \mathrm{m}^{2}\right)$. Vitamin C infusion at a daily dose of $65 \mathrm{mg} /$ $\mathrm{kg}$ was administered $(500 \mathrm{mg} C$ vit in $100 \mathrm{~mL} 5 \%$ dextrose solution) with the intention of decreasing fluid need. For fluid resuscitation, half of calculated volume was infused within first 8 hours, and second half within the remaining 16 hours. Intravenous (IV) blood samples were drawn, and urine cultures were obtained. Blood lactate, C-reactive protein, leucocyte, and procalcitonin levels were measured to monitor for sepsis. On third day of hospitalization, procalcitonin level was $8.5 \mathrm{ng} / \mathrm{dL}$ (normal: $<0.5 \mathrm{ng} / \mathrm{dL}$ ). Following the first 24 hours, IV fluid was provided to maintain daily urine output of $1.5-2 \mathrm{~mL} / \mathrm{kg}$. Metabolic acidosis, and $B E$ values were normalized with administration of albumin, erythrocyte, and colloidal suspensions. Antibiotherapy was not initiated within first 24 hours. Within the first 24 hours albumin replacement was not performed unless serum albumin levels fell below $2 \mathrm{~g} / \mathrm{L}$. Later, necessary replacements were provided to keep albumin levels above 2.5 $\mathrm{g} / \mathrm{L}$. Antibiotherapy was initiated based on results of blood tests and urine antibiograms. Calorie support was provided based on modified Currieri formula (basal metabolic rate $+15 \% \times$ surface area of burn percentage). Orogastric tube was inserted, and early enteral nutrition was initiated with $100 \mathrm{~mL}$ breast milk 8 times a day. Pediatrician did not recommend total parenteral nutrition. Patient was given Paramax supplement (paracetamol + phenobarbital) twice a day. On fourth day of hospitalization, patient was discharged because her spontaneous respiration was adequately efficient. Patient was monitored routinely and received supportive therapy. She was brought into operating room on 18th day of hospitalization for debridement and grafting. Since patient had full face and neck burn, she was evaluated as a case with difficult (grade IV) airway. Ear, nose, and throat (ENT) department was consulted for indication of preoperative tracheostomy, and surgical intervention was planned. During induction phase, 5-8\%
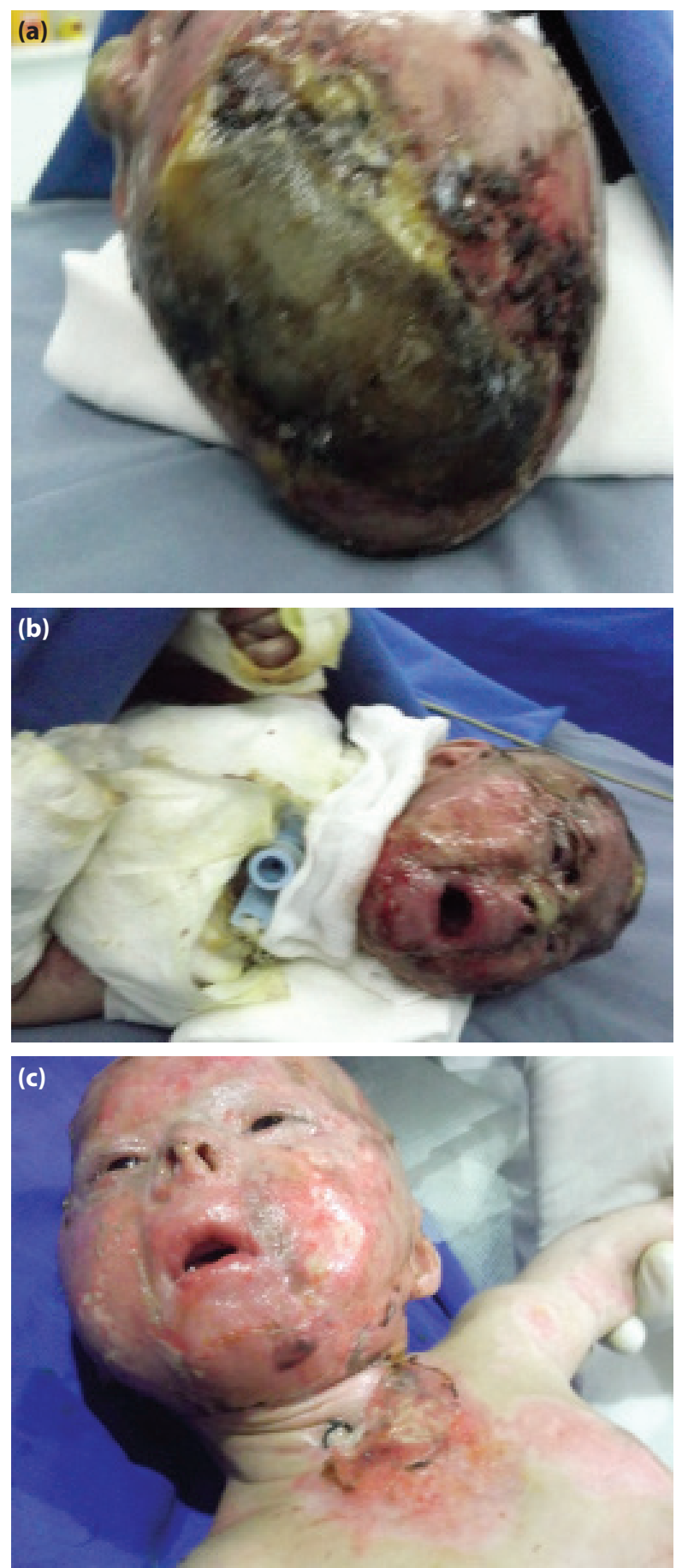

Figure 1. (a) Burned area of the patient extending up to vertex (b) its appearance following tracheotomy and (c) its decannulation.

sevoflurane inhalation was used, and IV fentanyl was administered at a dose of $10 \mathrm{mcg}$. Maintenance of airway patency was achieved using No. I Cobra perilaryngeal airway (CobraPLA; Engineered Medical Systems, Indianapolis, IN, USA) or laryngeal mask airway. Surgical tracheostomy was performed by an ENT specialist (Figure Ib). A tracheal cannula with No. 3 cuff was used. Anesthesia was main- 
tained with rocuronium bromide $5 \mathrm{mg}, 2 \%$ sevoflurane, and 3/3 O2/N2O mixture. Since patient tolerated muscle relaxants, and for complete postoperative paralysis, she was brought to neonatal intensive care unit, and high dose rocuronium was used during maintenance phase of anesthesia.

Ventilation with high gas flows was preferred (3/3O2/ $\mathrm{N} 2 \mathrm{O}$ ). A manual ventilation strategy that would maintain PIP and compliance of patient without allowing development of hypoxic state was applied. During the operation, full face and partial cranium grafts were performed, and remaining burned areas were debrided. During surgery, which lasted for nearly $31 / 2$ hours, patient bled 80 $\mathrm{mL}$, and urine output was $100 \mathrm{~mL}$. Replacement with 180 $\mathrm{mL}$ cristalloid and $60 \mathrm{~mL}$ erythrocyte suspension was provided. Laboratory values were as follows: arterial blood gas (ABG): $\mathrm{pH}$ : $7.5 \mathrm{I} \mathrm{mmHg}, \mathrm{PCO} 2: 31 \mathrm{mmHg}, \mathrm{PaO} 2: 73$ mmHg, HCO3: 24.7 mmoL/L, BE:I.7, SpO2: 96\%, Hb: I $2.1 \mathrm{~g} / \mathrm{dL}$, Hct: 39\%, FBG: I 25 mg/dL, Na: I 34 meq/L, K: 4.0 $\mathrm{meq} / \mathrm{L}$, and Ca: I.I5 mmoL/L. Immediately after the operation, tracheotomized patient was transported to ICU under free $\mathrm{O} 2$ support with mobile extremities, f: 38/min, HR: I28/bpm, and SpO2: 100\%. Patient was reconnected to SIMV-P mode MV. On 19th day of hospitalization, she was weaned from MV, and left to breathe room air. During her hospital stay, wound dressings were changed every other day under sedation with ketamine and midazolam. On 33rd day of hospitalization with GKS: 15, f: 35/min (at room temperature), HR max: I53 bpm, SpO2: 99\%, fever: $36.3^{\circ} \mathrm{C}$, procalcitonin (PCT): 0.162 nanogram/L, and normal electrolyte values, she was decannulated and transferred to the service (Figure Ic).

\section{DISCUSSION}

Burn injuries rank third among traumas with a mortal outcome. ${ }^{[1]}$ Arslan et al. ${ }^{[2]}$ performed a study with 375 pediatric cases, and reported that scald burns had lower mortality rates compared to other types of burns, and that hospital stays of infants were shorter than other age groups.

Surface area of the burn is very important for both surgeon and for monitoring patient during anesthesia and in ICU. Face and head burns cause vital problems because of the edema induced and close vicinity to airway.

It is well known that excessive fluid resuscitation can aggravate face, neck, and airway edema, as well as complicate oxygenation of the patient, leading to development of pulmonary edema associated with threat to life. ${ }^{[3]}$ Since present patient was a flame burn victim, she was intubated at an early stage due to potential risk of airway problem. During acute phase, it has been recommended that caliber of endotracheal tube should be equal to width of the small finger, or diameter of endotracheal tube to be used should be adjusted using Broselow tape (Armstrong Medical Industries, Lincolnshire, IL, USA)..$^{[3]}$ In infants and small children, use of endotracheal tubes without cuff is recommended. In cases with face and neck burns, since burn edema is not established yet, assurance of airway patency and safety using endotracheal tube stabilized with a lowpressure cuff may be a suitable approach. Timing of tracheostomy in small children is debatable; however, tracheostomy performed at an early stage is widely accepted. ${ }^{[4]} \mathrm{We}$ also found preoperative tracheostomy a suitable approach for our patient (Figure la). This approach provided ease of manipulation through airway, and ensured effective elimination of secretions. In burn patients, the need for energy and calories increases due to excessive hypermetabolism. In infants, rate of catabolism increases in proportion to size of burned area. It has been indicated that hypoglycemia increases mortality rates, while exogenous insulin has an anabolic effect and accelerates wound healing. ${ }^{[5]}$ However, since in our patient glucose levels led a labile course, insulin treatment was not initiated. It has been indicated that beta-blocker agent propranolol exerts anticatabolic effect by increasing protein synthesis, and also decreases peripheral lipolysis. Thanks to these effects, it is widely used in burn patients. ${ }^{[3]}$ In the present case, due to side effects peculiar to beta-blockers (hypotension, bradycardia, bronchoconstriction), and inconvenient health state of the patient, propranolol treatment was not initiated. Some authors have stated that vitamin $\mathrm{C}$ has edema-decreasing effect by lowering fluid requirement during fluid resuscitation. ${ }^{[6,7]}$ Vitamin $C$ infusions were administered to present patient for 5 days, and beneficial effects in prevention of edema were observed. In pediatric burn cases, since prophylactic antibiotic use is thought to increase bacterial resistance and depress the immune system, antibiotherapy based on the results of antibiograms is concluded by the majority to be a more appropriate approach. ${ }^{[8-10]}$ Therefore, prophylactic antibiotics were not used for the present patient; instead, antibiotherapy was performed based on results of antibiograms.

\section{Conclusion}

Education of the public concerning prevention of pediatric burn cases (children should be kept away from inflammable and caustic materials) via print and visual media carries utmost importance. It should not be forgotten that multidisciplinary approach and tracheotomy performed at an early stage are important advantages for the patient while in ICU, and for surgical interventions and clinical followups.

\section{REFERENCES}

1. Tarim A, Nursal TZ, Yildirim S, Noyan T, Moray G, Haberal M. 
Epidemiology of pediatric burn injuries in southern Turkey. J Burn Care Rehabil 2005;26:327-30.

2. Arslan H, Kul B, Derebaşınlıŏlu H, Çetinkale O. Epidemiology of pediatric burn injuries in Istanbul, Turkey. Ulus Travma Acil Cerrahi Derg 2013;19:123-6.

3. Lee Joe, Herdnon DE. The pediatric burn patient. In: Herdnon DE, editor. Total burn care. 3rd ed. Philedelphia: WB Saunders; 2007. p. 485-95.

4. Palmieri TL, Jackson W, Greenhalgh DG. Benefits of early tracheostomy in severely burned children. Crit Care Med 2002;30:922-4.

5. Gore DC, Chinkes DL, Hart DW, Wolf SE, Herndon DN, Sanford AP. Hyperglycemia exacerbates muscle protein catabolism in burninjured patients. Crit Care Med 2002;30:2438-42.

6. Schulman CI, King DR. Pediatric fluid resuscitation after thermal injury. J Craniofac Surg 2008;19:910-2.

7. Kut A, Basaran O, Noyan T, Arda IS, Akgün HS, Haberal M. Epidemiologic analysis of patients with burns presenting to the burn units of a University Hospital Network in Turkey. J Burn Care Res 2006;27:161-9.

8. Senel E, Yasti AC, Reis E, Doganay M, Karacan CD, Kama NA. Effects on mortality of changing trends in the management of burned children in Turkey: eight years' experience. Burns 2009;35:372-7.

9. Foglia RP, Moushey R, Meadows L, Seigel J, Smith M. Evolving treatment in a decade of pediatric burn care. J Pediatr Surg 2004;39:95760

10. Reis E, Yasti AC, Kerimoğlu RS, Dolapçi M, Doğanay M, Kama NA. The effects of habitual negligence among families with respect to pediatric burns. Ulus Travma Acil Cerrahi Derg 2009;15:607-10.

\section{Tam Yüz ve Boyun Yanıklı İnfantta Zor Havayolu Yönetimi}

Yaşamın ilk iki dekadında oluşan yanıkların kazalara bağlı ve önlenebilir olduğu ifade edilmektedir. Illk dekatta haşlanma yanıkları en sık görülüyorken, alev nedenli yanıklar infantlarda yüksek mortalite ve morbidite oranları ile seyretmektedir. Bu yazıda, hastanın erkek kardeşinin kibritle oynaması nedeniyle kundağının tutuşması üzerine oluşan alev nedeniyle yüz, boyun ve vücudunda Lund Browder skalası'na göre \% 8 vücut alanında ikinci ve üçüncü derece yanığı olan, yüz ve dudak ödemi nedeniyle zor havayolu (Grade IV) olarak değerlendirilen 35 günlük infant olgusunun uygun anestezi yönetimi ve multidisipliner yaklaşımla yoğun bakım tedavisi sunuldu.

Anahtar Sözcükler: Havayolu tıkanıklı̆̆l; yanıklar; infant. 